\title{
CONE-BEAM COMPUTED TOMOGRAPHY EVALUATION OF DENTOSKELETAL EFFECTS PRODUCED BY THE BONDED EXPANDER AND HYRAX: A PILOT STUDY
}

\author{
AVALIAÇÃO POR TOMOGRAFIA COMPUTADORIZADA DE FEIXE CÔNICO DOS \\ EFEITOS DENTOESQUELÉTICOS PRODUZIDOS PELO EXPANSOR COLADO E \\ HYRAX: UM ESTUDO PILOTO
}

\author{
Guilherme de Araújo ALMEIDA ${ }^{1}$; Joana Cristina dos SANTOS MENEZES ${ }^{2}$; \\ Éverton Ribeiro LELIS ${ }^{3}$; Marina Guimarães ROSCOE ${ }^{4}$; Isadora Moraes Mundim PRADO ${ }^{5}$; \\ Asbel Rodrigues MACHADO ${ }^{6}$; Alfredo Júlio FERNANDES NETO ${ }^{7}$ \\ 1. Professor, Department of Pediatric Dentistry and Orthodontics, Federal University of Uberlandia, Uberlândia, Minas Gerais, Brazil. \\ galmeidaorto@prove.ufu.br; 2. Orthodontist, Private Practice; 3. PhD Student, Department of Orthodontics, São Paulo State University, \\ Araçatuba, São Paulo, Brazil; 4. PhD Student, Department of Biomaterials and Oral Biology, University of São Paulo, São Paulo, São \\ Paulo, Brazil; 5. Post-graduate Student, Department of Occlusion, Fixed Prosthodontics and Dental Materials, Federal University of \\ Uberlandia, Uberlândia, Minas Gerais, Brazil; 6. Oral and Maxillofacial Radiologist, Private Practice; 7. Professor, Department of \\ Occlusion, Fixed Prosthodontics and Dental Materials, Federal University of Uberlandia, Uberlândia, Minas Gerais, Brazil. \\ alfredon@ufu.br
}

\begin{abstract}
The dentoskeletal effects produced by the bonded expander, principally the vertical ones, are controversial in the literature when compared with the effects produced by the hyrax, and have also been scarcely studied by means of cone-beam computed tomography (CBCT). This study aimed to evaluate the horizontal and vertical dentoskeletal effects produced by the bonded expander and by the hyrax using CBCT. The study sample consisted of ten patients, divided equally into two groups according to facial and cephalometric features: group 1, vertical facial growth pattern (two males, three females; mean age, 7.7 years) and group 2, normal facial growth pattern (three males, two females; mean age, 8.3 years), treated by bonded expander and hyrax, respectively. The patients were subjected to a CBCT scan before expansion and another scan four months after the end of the activations, when the expander was removed. Within each group and between the groups the horizontal and vertical effects were assessed using Student's $t$-test. The sample size was predetermined, and 5 patients were needed in each group to detect the differences at $P<0.05$ with $90 \%$ power. Among the horizontal changes assessed, the nasal floor width $(P=0.03)$ and the greater internal width in the posterior region $(P=0.00)$ showed a statistically significant increase only for group 1 , and the mandibular molar verticality showed a statistically significant increase only for group 2 . The vertical changes showed no statistical differences within groups $(P>0.05)$. Comparing the two groups there were no statistical differences for any assessed change $(P>0.05)$. Considering there were no differences of the effects between the appliances, the bonded expander produced no greater vertical control compared to the hyrax. Nevertheless, further study is recommended in a larger sample size using CBCT.
\end{abstract}

KEYWORDS: Orthodontic Appliances. Palatal Expansion Technique. Malocclusion.

\section{INTRODUCTION}

Over the years, different appliances have been developed for performing the rapid maxillary expansion (RME) such as the hyrax (BIEDERMAN, 1968) and the bonded expander (COHEN; SILVERMAN, 1973). Several studies have addressed the dentoskeletal effects of these expander appliances (AKYALCIN et al., 2013; ASANZA et al., 1997; BAYSAL et al., 2013; FARRONATO et al., 2008; GARIB et al., 2005; GARRETT et al., 2008; IWASAKI et al., 2014; LAGRAVÈRE et al., 2010; REED et al., 1999; RODRIGUES et al., 2012; SARVER; JOHNSTON, 1989), however, the comparison between them still remains controversial, especially regarding to the vertical effects. Some authors concluded that the bonded expander increases the transverse dimension of the maxilla, but limits or even eliminates changes in vertical dimension (ASANZA et al., 1997; SARVER; JOHNSTON, 1989). This is possible because the acrylic on the posterior region works like a bite block, inhibiting the eruption of the posterior teeth during treatment (SARVER; JOHNSTON, 1989). Nevertheless, long terms evaluations showed that changes in the vertical and anteroposterior dimensions were negligible when patients were treated with hyrax without any kind of vertical control (LAGRAVËRE et al., 2010).

Most evaluations of dentoskeletal effects of RME with bonded expander were performed through the analysis of dental casts and cephalometric radiographs (ASANZA et al., 1997; IWASAKI et al., 2014; REED et al., 1999; 
SARVER; JOHNSTON, 1989). However, these methods are not appropriate for examining the changes during and after RME therapy because they are based on a two-dimensional representation of a three-dimensional object (AKYALCIN et al., 2013). Conventional radiographs can cause an overlap of the images, which compromises the diagnostic accuracy (GARIB et al., 2005). With the advent of the cone-beam computed tomography (CBCT), the clinician is enabled to acquire images in any plane without overlapping structures, and allowed to evaluate skeletal and dental changes quantitatively and three-dimensionally with minimal distortion (AKYALCIN et al., 2013; BAYSAL et al., 2013).

The purpose of this study was to evaluate the horizontal and vertical dentoskeletal effects occurred after the RME in patients treated by a hyrax or a bonded expander, using the CBCT. The hypotheses tested were that the hyrax and the bonded expander appliances would present significant differences in their dentoskeletal effects after the RME; there would also be a greater vertical control when using the bonded expander appliance compared to the hyrax.

\section{MATERIAL AND METHODS}

\section{Study participants and design}

This study was approved by the Ethical Research Committee at the Federal University of Uberlandia - UFU, Uberlandia, Brazil (approval number 359/08). Sample size was predetermined, and five patients were required in each group to detect differences at $P<0.05$ with $90 \%$ power. Ten patients in need of orthodontic treatment, who sought the Brazilian Dental Association Uberlandia Section (ABO, Uberlandia, Brazil), were asked to participate in the study. Considering the radiation exposure of CBCT compared to conventional radiographs, the Ethical Committee allowed to plan only a pilot study first. The criteria for inclusion in the research were as follows: clinical signs of transverse maxillary deficiency with bilateral posterior crossbite or unilateral functional crossbite; patients should be at the first transitional period or the intermediate period of the mixed dentition; no previous orthodontic treatment or periodontal disease; absence of metallic restorations in posterior teeth or craniofacial anomalies; presence of upper first permanent molar.

The ten patients were divided into two groups (group 1 and group 2), according to the facial and cephalometric features presented. Group 1 was composed by 3 female and 2 male patients (mean age 7 years 9 months), with facial and cephalometric features showing vertical patterns more pronounced, as mandibular planes inclined, growth excessively vertical (SN.GoGn $>32^{\circ}$ ) (RIEDEL, 1952), convex profile and therefore requiring a greater vertical control over the procedure of the maxillary. Group 2 was composed by 2 female and 3 male patients (mean age 8 years 4 months), with balanced facial and cephalometric features. RME was carried out using a bonded expansor appliance (Figure 1A) in group 1 and a conventional hyrax appliance (Figure 1B) in group 2.
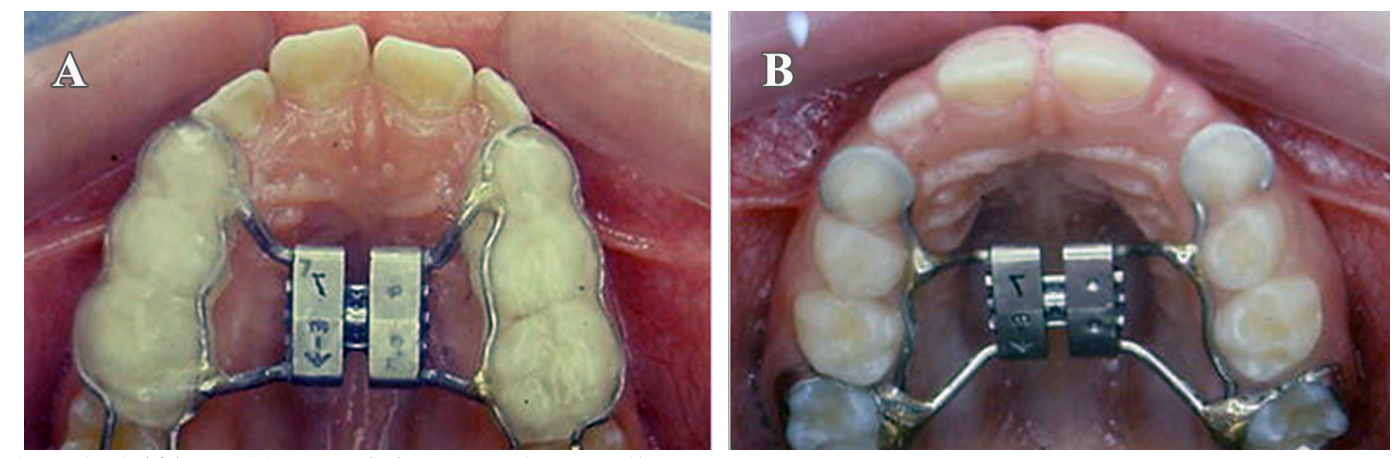

Figure 1. The bonded (A) and hyrax (B) expander appliances.

The activation of the RME appliances was made twice a day, one-quarter turn in the morning and one-quarter turn in the evening. Maxillary expansion was determined by an increase in the intermolar width until overcorrection of approximately 2 to $3 \mathrm{~mm}$. All patients underwent examination with $\mathrm{CBCT}$; the records were obtained immediately pre-treatment $\mathrm{T} 1$ and four months after the end of the activations T2. In this stage, the expander was removed to achieve the second CBCT scan T2 and the activation was conferred by counting the number of turns, rotating the screw to its initial position.

A NewTom 3G (Quantitative Radiology s.r.l., Verona, Italy) was used to obtain the scans. During the CT scans the following actions were 
taken to standardization of the patient head position: the Camper Plane was perpendicular to the ground; the longitudinal laser beam was positioned through the facial midline; and, the transverse laser beam was positioned through the lateral corner of the eyes. The axial slice thickness was set at $0.5 \mathrm{~mm}$ and the linear and angular measurements were made by the radiologist using another software coupled to the NewTom 3G, called "Basic 3G" (Quantitative Radiology s.r.1.), which gives measures scale of 1:1. Evaluations were performed on axial, coronal and sagittal slices. From the axial images it was selected one immediately preceding the complete separation of the roots of the first right upper molar (furcation area). In the image it was traced a line connecting the most prominent point of the palatal root, in relation to the palatal bone plate, of the first upper right molar to the most prominent point of the palatal root of the maxillary left first molar. The coronal slices were made parallel to that line and the sagittal slices were made passing through the center of the incisal edge of the maxillary right central incisor tooth. The thickness was set at $1.0 \mathrm{~mm}$ and the width at $80 \mathrm{~mm}$. One of the researchers measured the material twice, with at least a 1-week interval between the first and second recordings. It was used the average value in millimeters of the first and second readings.

The parameters applied are shown in Figures 2, 3 and 4.

\section{Axial slice}

Buccal bone plate thickness: distance between the buccal bone plate and the most prominent point of the mesiobuccal root surface of the maxillary right first molar (Figure 2).

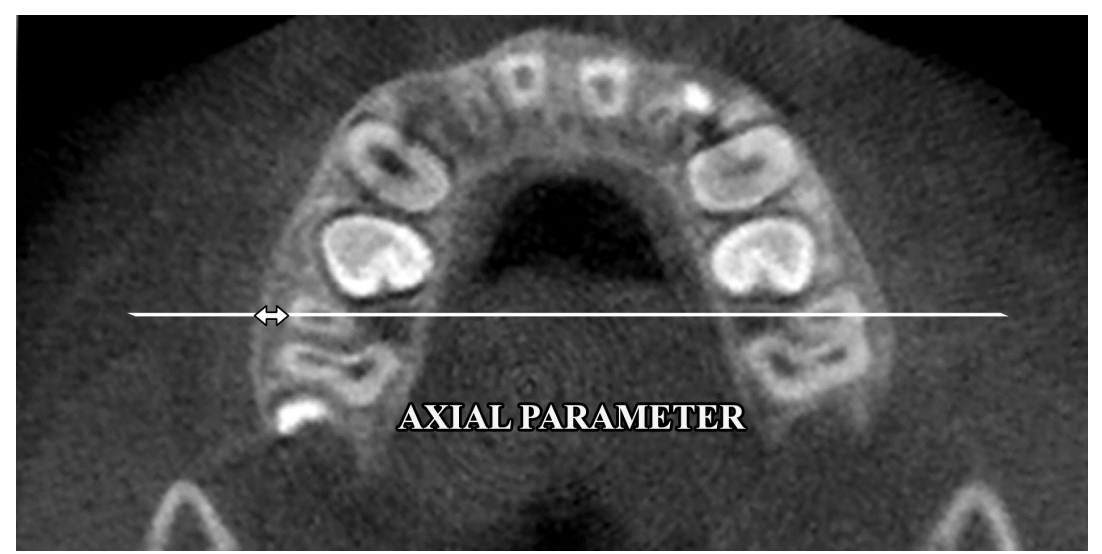

Figure 2. Axial slice used to evaluate the buccal bone plate thickness.

\section{Coronal slices (horizontal changes)}

The coronal parameters 1 to 4 were measured based on a line passing through the points of union of the palatal root, of the buccal root, of the right maxillary first molar and of the left maxillary first molar (Figure 3).

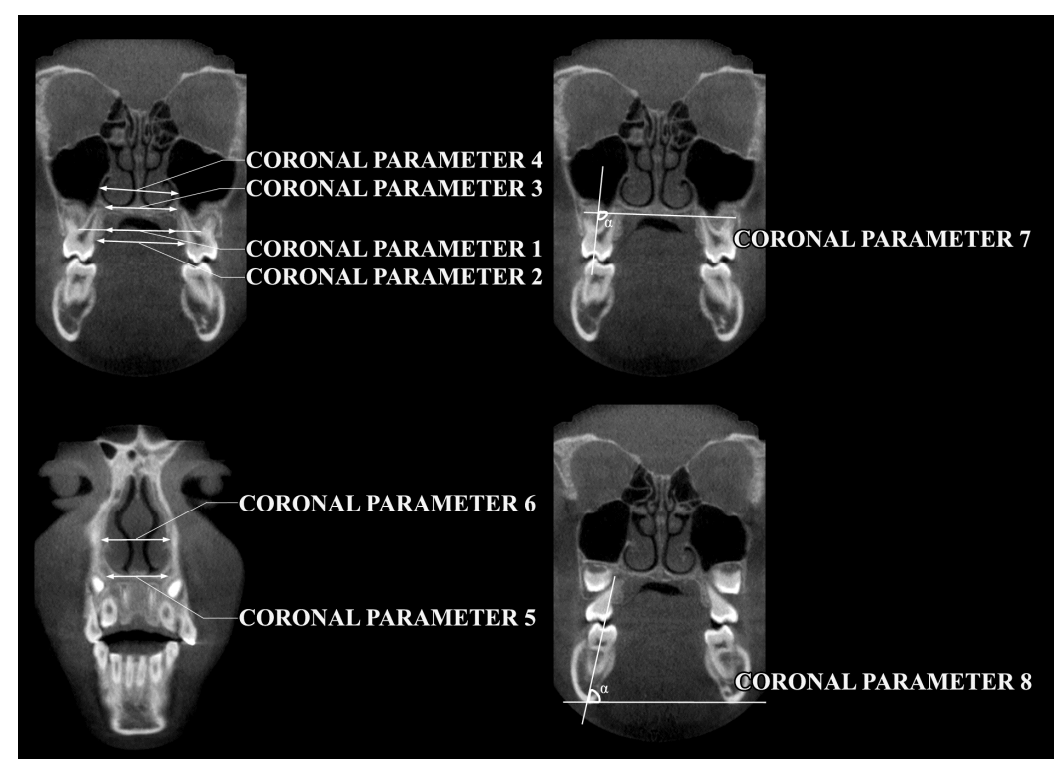

Figure 3. Coronal evaluation parameters. 
1. Distance between the palatal bone of ridge surface on the right side and the palatal bone of ridge surface on the left.

2. Distance between the top of the bone crest palatal on the right side and the top of the bone crest palatal on the left.

3. Nasal floor width in the posterior region.

4. Greater internal width in the posterior nasal region.

The coronal parameters 5 and 6 were measured based on a line passing through the center of the cervical third of the upper canines erupted (Figure 3).

5. Nasal floor width in the anterior region.

6. Greater internal width in the anterior nasal region.

The coronal parameters 7 and 8 were measured based on a line passing through the center of the trifurcation of the first upper and lower molars, respectively (Figure 3).

7. Upper molar verticality: the angle of intersection of a first line passing parallel to the image of the hard palate and of one passing through the long axis of the first right upper molar.

8. Lower molar verticality: the angle of intersection of a first line passing through the long axis of the mandibular first molar with a second one bilaterally tangent the image of the mandibular lower edge.

\section{Sagittal slices (vertical changes)}

The sagittal parameters 1 to 4 were measured on a sagittal image, with a thickness of 1 $\mathrm{mm}$, passing through the center of the incisal edge of the upper right central incisor (Figure 4).

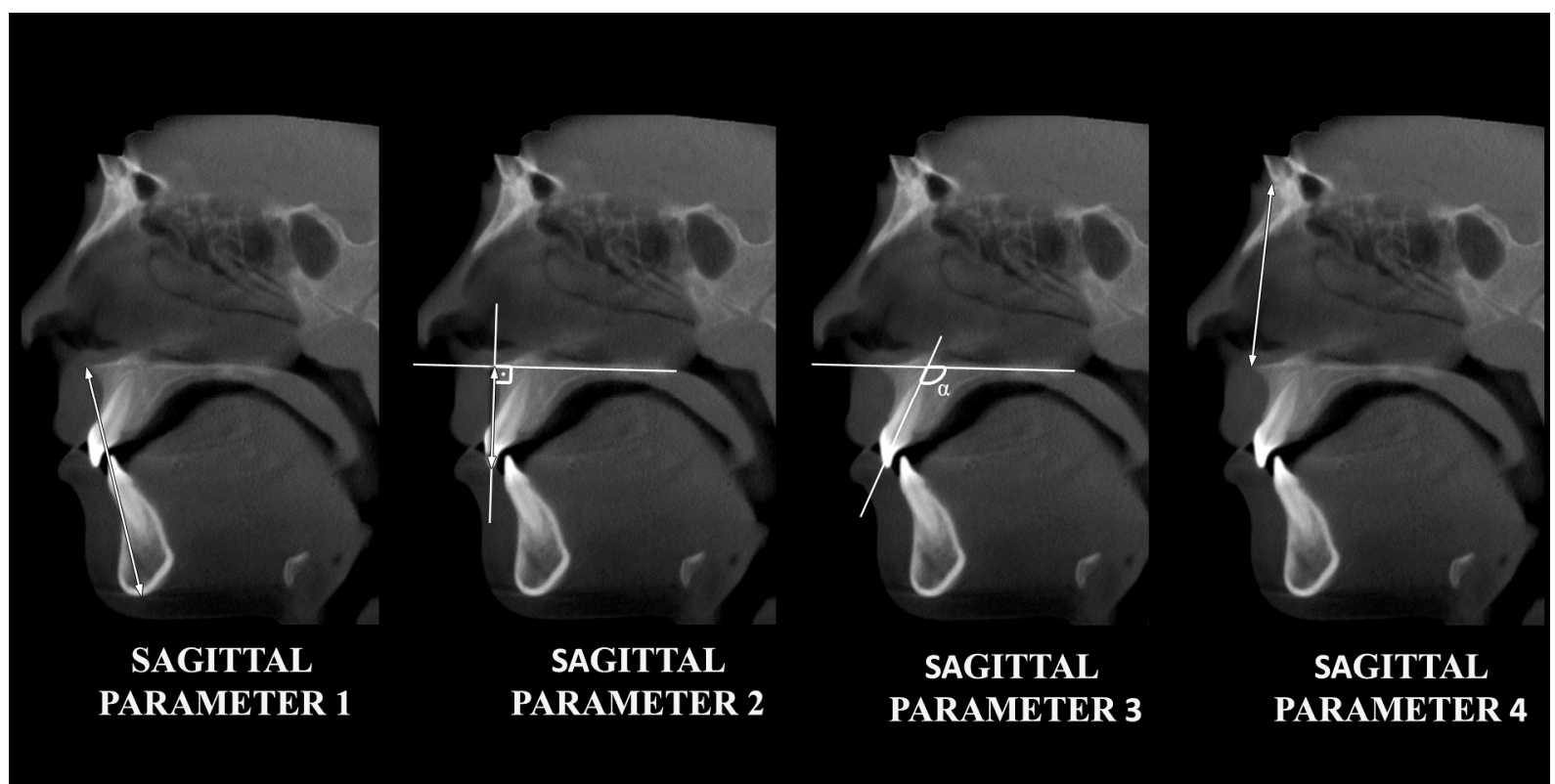

Figure 4. Sagittal evaluation parameters.

1. Distance between the anterior nasal spine and the menton point.

2. Distance between the incisal edge of the maxillary right central incisor and a line linking the anterior and posterior nasal spine.

3. Upper right incisor verticality: the angle of intersection of a first line connecting the anterior nasal spine and posterior nasal spine and of a second line on the long axis of the maxillary right central incisor, passing through the incisal edge of maxillary right central incisor tooth.

4. Distance between the anterior nasal spine and the nasion point.

\section{Statistical analysis}

The data were analyzed with the SPSS software for Windows 15.0 (SPSS Inc., Chicago, USA). Student's t-test was performed to analyze and compare the dentoskeletal changes of the two groups in study. A significance level of $\alpha=0.05$ was considered.

\section{RESULTS}

The mean values, standard deviations and statistical significance $(P$ value) for the changes resulting from the RME in groups 1 and 2 as well as for the comparative changes between the two groups are shown in Tables 1, 2 and 3, respectively. 
Table 1. Changes in the bonded expander group (unit: $\mathrm{mm}$ ).

\begin{tabular}{lcccc}
\hline Parameter & T1 - T2 Mean & Deviation & $\boldsymbol{t}$ statistic & $\boldsymbol{P}$ value \\
\hline Axial & 0.92500 & 0.74106 & 2.49643 & 0.0880 \\
Coronal 1 & -0.900000 & 1.42127 & -1.266476 & 0.2947 \\
Coronal 2 & -2.350000 & 0.35119 & -13.38313 & $0.0009^{*}$ \\
Coronal 3 & -1.825000 & 0.94296 & -3.870805 & $0.0305^{*}$ \\
Coronal 4 & -2.050000 & 0.49329 & -8.31157 & $0.0036^{*}$ \\
Coronal 5 & -1.100000 & 1.14601 & -1.919708 & 0.1507 \\
Coronal 6 & -0.850000 & 0.55076 & -3.08666 & 0.0539 \\
Coronal 7 & -0.600000 & 1.60208 & -0.749025 & 0.5082 \\
Coronal 8 & -2.750000 & 1.82117 & -3.020034 & 0.0568 \\
Sagittal 1 & -1.150000 & 1.90000 & -1.210526 & 0.3127 \\
Sagittal 2 & -1.725000 & 1.26853 & -2.719685 & 0.0726 \\
Sagittal 3 & 1.57500 & 2.10297 & 1.49788 & 0.2311 \\
Sagittal 4 & -0.775000 & 0.88459 & -1.752224 & 0.1780 \\
\hline
\end{tabular}

* Statistically significant if $P$ value $<0.05$ (Student's t-test).

Table 2. Changes in the hyrax expander group (unit: $\mathrm{mm}$ ).

\begin{tabular}{lcccc}
\hline Parameter & T1 - T2 Mean & Deviation & $\boldsymbol{t}$ statistic & $\boldsymbol{P}$ value \\
\hline Axial & 0.5250000 & 1.00457 & 1.04522 & 0.3727 \\
Coronal 1 & -2.400000 & 1.14601 & -4.188454 & $0.0248^{*}$ \\
Coronal 2 & -3.700000 & 1.63911 & -4.514658 & $0.0203^{*}$ \\
Coronal 3 & -2.050000 & 1.54164 & -2.659498 & 0.0764 \\
Coronal 4 & -2.650000 & 2.05345 & -2.581019 & 0.0817 \\
Coronal 5 & -1.100000 & 0.74386 & -2.957531 & 0.0597 \\
Coronal 6 & -1.625000 & 1.10868 & -2.93142 & 0.0609 \\
Coronal 7 & -4.250000 & 4.07635 & -2.085196 & 0.1284 \\
Coronal 8 & -3.825000 & 1.67008 & -4.580619 & $0.0195^{*}$ \\
Sagittal 1 & -1.175000 & 1.75381 & -1.339943 & 0.2727 \\
Sagittal 2 & -1.125000 & 0.97425 & -2.309464 & 0.1041 \\
Sagittal 3 & 4.55000 & 3.82317 & 2.38022 & 0.0976 \\
Sagittal 4 & -0.675000 & 0.84212 & -1.603096 & 0.2072 \\
\hline
\end{tabular}

*Statistically significant if $P$ value $<0.05$ (Student's t-test). 
Table 3. Comparative changes resulted from the RME between the bonded and hyrax expanders (unit: $\mathrm{mm}$ ).

\begin{tabular}{lcccccc}
\hline Parameter & $\begin{array}{c}\text { Average } \\
\text { (bonded) }\end{array}$ & $\begin{array}{c}\text { Deviation } \\
\text { (bonded) }\end{array}$ & $\begin{array}{c}\text { Average } \\
\text { (hyrax) }\end{array}$ & $\begin{array}{c}\text { Deviation } \\
\text { (hyrax) }\end{array}$ & t test & $\boldsymbol{P}$ value \\
\hline Axial & 0.9250 & 0.74106 & 0.5250 & 1.00457 & 0.64 & 0.5453 \\
Coronal 1 & -0.9000 & 1.42127 & -2.4000 & 1.14601 & 1.64 & 0.1515 \\
Coronal 2 & -2.3500 & 0.35119 & -3.7000 & 1.63911 & 1.61 & 0.1584 \\
Coronal 3 & -1.8250 & 0.94296 & -2.6500 & 2.05345 & 0.73 & 0.4928 \\
Coronal 4 & -2.0500 & 0.49329 & -2.0500 & 1.54164 & 0.00 & 1.0000 \\
Coronal 5 & -1.1000 & 1.14601 & -1.6250 & 1.10868 & 0.66 & 0.5347 \\
Coronal 6 & -0.8500 & 0.55076 & -1.1000 & 0.74386 & 0.54 & 0.6085 \\
Coronal 7 & -0.6000 & 1.60208 & $-4,2500$ & 4,07635 & 1.68 & 0.1474 \\
Coronal 8 & -2.7500 & 1.82117 & -3.8250 & 1.67008 & 0.87 & 0.4177 \\
Sagittal 1 & -1.1500 & 1.90000 & -1.1750 & 1.75381 & 0.02 & 0.9852 \\
Sagittal 2 & -1.7250 & 1.26853 & -1.1250 & 0.97425 & -0.75 & 0.4815 \\
Sagittal 3 & 1.5750 & 2.10297 & 4.5500 & 3.82317 & -1.36 & 0.2216 \\
Sagittal 4 & -0.7750 & 0.88459 & -0.6750 & 0.84212 & -0.16 & 0.8753 \\
\hline Tistically significant if $P$ value $<0.05($ Student's t-test) & & & &
\end{tabular}

$*$ Statistically significant if $P$ value $<0.05$ (Student's t-test).

For the bonded expansor group, Student's ttest showed that only the coronal parameters $2(P=$ $0.00), 3(P=0.03)$ and $4(P=0.00)$ were significant. Numerically, it could be seen rising values for most parameters evaluated, except for the axial parameter (assessment of the buccal bone plate thickness), which showed an average reduction of $0.925 \mathrm{~mm}$; and the sagittal parameter 3 (assessment of the upper right incisor verticality), which showed a reduction of $1.57^{\circ}$ on average.

For the hyrax group, Student's t-test showed that only the coronal parameters $1(P=0.02), 2(P=$ $0.02)$ and $8(P=0.01)$ were significant. Likewise, in group 1 it could be numerically seen rising values for most parameters evaluated, except for the axial parameter (assessment of the buccal bone plate thickness), which showed an average reduction of $0.525 \mathrm{~mm}$; and the sagittal parameter 3 (assessment of the upper right incisor verticality), which showed a reduction of $4.55^{\circ}$ on average.

Analyzing the two groups, Student's t-test showed no statistically significant differences in the parameters evaluated when hyrax and bonded expansor appliances $(P>0.05)$ effects were compared.

\section{DISCUSSION}

Some authors (ASANZA et al., 1997; SARVER; JOHNSTON, 1989) attribute to the bonded expander, a better vertical control when compared to conventional expanders such as haas and hyrax expanders. Thus, in this study, subjects with a definite tendency to vertical craniofacial growth were undergoing expansion using the bonded expander. On the other hand, individuals with balanced craniofacial growth trend were treated with hyrax expander.

The dentoskeletal effects resulted from the RME were quantified and compared among patients treated by a bonded expander (COHEN; SILVERMAN, 1973) or a hyrax (BIEDERMAN, 1968), using CBCT. This system has the advantage of reducing measurement errors because it is possible to visualize the teeth in sagittal, coronal and axial planes without image superimpositions (AKYALCIN et al., 2013; BAYSAL et al., 2013).

The axial parameter (buccal bone plate thickness) showed numerical decreases in both groups. However, there were no statistical differences. This find corroborates the recent study carried out by Baysal et al. (2013). Although this CBCT study (BAYSAL et al., 2013) did not find a 
statistical difference in the furcation area of the first molars, between the periods after retention and before expansion, it found differences in other regions of the roots and other teeth as well. The coronal parameter 1 evaluated the maxillary transverse dimension and showed numerical increases in both groups. These results corroborate other findings in the literature, which also report increase in skeletal transverse dimension after the RME (HAAS, 1970; RODRIGUES et al., 2012; SARVER; JOHNSTON, 1989). Nonetheless, only group 2 presented a statistically significant difference between the initial and final average. This might had occurred due to a lower standard deviation and a greater activation of the screw in this group (6.5 laps in the hyrax expander and 5.25 laps in the bonded expander).

The opening of the mid-palatal suture causes downward and backward rotation of the mandible and increases lower anterior facial height as a direct effect of vertical displacement of the maxilla (ASANZA et al., 1997; HAAS, 1970). Assessing the lower anterior facial height parameter (sagittal parameter 1), although patients treated by the bonded expander showed a slightly average difference between stages $\mathrm{T} 1$ and $\mathrm{T} 2$, this difference was not statistically significant when compared with patients treated by hyrax expander. These finds corroborate Reed et al. (1999), that compared the treatment outcomes between banded and bonded RME appliances, by means of cephalometric radiographs and orthodontic study casts, and found no statistically significant differences between the two appliances.

Several studies have exposed the effects of the RME in the nasal cavity (FARRONATO et al., 2008; GARIB et al., 2005; IWASAKI et al., 2014). Additionally, this study performed measurements of nasal cavity in stages T1 and T2 of treatment. The nasal floor width in the posterior region (coronal parameter 3) showed a numerical increase in both groups; however it showed a statistically significant increase only in group 1. In the anterior region (coronal parameter 5), it was observed increased values in both groups, although none statistically significant. Evaluating the greater internal width in the posterior and anterior nasal region (coronal parameters 4 and 6 , respectively), only group 1 showed a statistically significant difference, identified in the posterior region. Increases in the posterior region corresponded to $39.04 \%$ of the amount of activation of the screw in group 1 and $31.53 \%$ of the amount of activation of the screw in group 2, approaching the values found in the literature, as the $37.2 \%$ reported by Garret et al.
(2008). through hyrax screw, and the $33.3 \%$ reported by Garib et al. (2005). This increase may contribute to the decrease of nasal resistance to the airflow (FARRONATO et al., 2008; GARIB et al., 2005; HAAS, 1970).

The RME also promotes dentoalveolar changes. Slight extrusion also occurs in the posterior dentoalveolar structures during tipping (LAGRAVÈRE et al., 2010). Buccal tipping and extrusion of the maxillary posterior dentoalveolar structures result in downward and backward rotation of the mandible, an increased mandibular plane angle, and a reduced bite (SARVER, JOHNSTON, 1989). The coronal parameter 2 evaluated not only the transverse maxillary growth, but also the inclination or expansion of the alveolar processes. It was noted that these increases were higher than those reported by the measurement of coronal parameter 1 . This effect demonstrates a decrease of the magnitude of the maxillary expansion in the direction of the occlusion of the maxillary basal area, according to the literature (BISHARA; STALEY, 1987; SARVER, JOHNSTON, 1989). These increases were statistically significant in both groups.

The coronal parameter 8 was calculated in order to observe the stabilization of the anchorage (first molar). It was detected an increase angle value, characterizing a flaring of the molar acting as an anchorage. However, these values were not statistically significant, probably due to the large standard deviations observed in both groups. This dental effect, characterized by the flaring of the first molar, caused a thickness reduction of the buccal bone plate, which was noted by the axial parameter measurement. This reduction of the buccal bone plate thickness represents the absence of equivalent compensatory bone apposition on the buccal periosteum, from the beginning of this process to the final four months of retention with the appliance. These results corroborate previous studies that reported a decrease in buccal bone plate after the RME (GARIB et al., 2005; GARRETT et al., 2008). Nevertheless, this reduction was not statistically significant for any of the evaluated groups.

To evaluate the effects of RME in the upper incisor, some measurements were made. Among them, the one that evaluated the extrusion of the upper incisor (sagittal parameter 2) deserves more emphasis. Group 1 showed a numerically significant increase, demonstrating that a possible dental extrusion movement occurred in the upper right incisor, which is in accordance with the literature (BISHARA; STALEY, 1987; SARVER, 
JOHNSTON, 1989). However, this was not statistically significant. On the other hand, Group 2 expressed only a small increase in this measurement. These differences may have occurred due to the bite opening caused by the installation of the bonded expander, which facilitates the extrusion.

Regarding to the upper right incisor verticality (sagittal parameter 3 ), it was observed a decrease in the angle value in both groups, indicating a verticality with a relative extrusive movement, which is also in accordance with the literature (BISHARA; STALEY, 1987; SARVER, JOHNSTON, 1989). Nevertheless, the values found were not statistically significant. The mandibular effects of RME were evaluated to detect the existence of a lateral movement of the molars (coronal parameter 8). Only group 2 showed a statistically significant increase in this angle, proving the verticality suffered by the lower molar after the RME, due to the occlusal force changes and to the muscular balance reestablishment (reduction of buccinator pressure) (BISHARA; STALEY, 1987).

The present study showed no statistically significant differences between the groups when using the CBCT. Consequently, there was no finding of a greater vertical control when the bonded expander was used compared to hyrax. Nevertheless, the sample size of this study must be considered. This research was conducted using a small sample due to restrictions made by the ethics committee, considering the radiation exposure of the cone-beam computed tomography and the mean age required. Therefore, it is suggested for future studies in which long-term evaluations, covering a larger number of patients, should be carried out to investigate all these dentoskeletal changes when RME is performed.

\section{CONCLUSION}

Within the limitations of this study, it was not found any statistically significant differences between the two appliances. Thus, there was no finding of a greater vertical control when using the bonded expander appliance compared to the hyrax.

\section{ACKNOWLEDGMENTS}

The authors would like to thank the Tomoface Tomografia Volumétrica Facial Ltda for the volumetric CT support.

RESUMO: Os efeitos dentoesqueléticos produzidos pelo expansor colado, principalmente os efeitos verticais, são controversos na literatura quando comparados aos efeitos produzidos pelo expansor hyrax, e pouco estudado por meio de tomografia computadorizada de feixe cônico (TCFC). O objetivo deste estudo foi avaliar os efeitos dentoesqueléticos horizontais e verticais produzidos pelo expansor colado e pelo hyrax, utilizando-se TCFC. A amostra do estudo consistiu de cinco pacientes, divididos igualmente em dois grupos de acordo com as características faciais e cefalométricas: grupo 1, padrão de crescimento facial vertical (dois do sexo masculino, três do sexo feminino, idade média 7,7 anos), e grupo 2, padrão de crescimento facial normal (três do sexo masculino, duas do sexo feminino, idade média 8,3 anos) tratados com expasor colado e hyrax, respectivamente. Os pacientes foram submetidos à escaneamento de TCFC antes da expansão e após quatro meses da última ativação, quando o expansor foi removido. Nas comparações intra e inter-grupos, os efeitos horizontais e verticais foram avaliados por meio do teste $t$ de Student. $\mathrm{O}$ tamanho da amostra foi pré-determinado, e cinco pacientes foram necessários em cada grupo para detectar diferenças para $P<0,05$ e com $90 \%$ de poder. Dentre as alterações horizontais avaliadas, a largura do assoalho nasal $(P=0,03)$ e a maior largura nasal interna na região posterior $(P=0,00)$ mostraram aumento estatisticamente significante apenas para o grupo $1, \mathrm{e}$ a verticalização do molar inferior mostrou aumento estatisticamente significante apenas no grupo $2(P=0,01)$. As alterações verticais avaliadas não demonstraram diferença estatística intra-grupos. Na comparação inter-grupos não foi encontrada diferença estatística em nenhum parâmetro avaliado $(P>0,05)$. Dado que não houve diferença na comparação inter-grupos, o expansor colado não produziu maior controle vertical em relação ao hyrax. No entanto, é recomendada a realização de mais estudos com maior amostra utilizando-se TCFC.

PALAVRAS-CHAVE: Aparelhos Ortodônticos. Técnica de Expansão Palatina. Má Oclusão.

\section{REFERENCES}

AKYALCIN, S.; SCHAEFER, J. S.; ENGLISH, J. D.; STEPHENS, C. R.; WINKELMANN, S. A cone-beam computed tomography evaluation of buccal bone thickness following maxillary expansion. Imaging Sci Dent., v. 43, n. 2, p. 85-90, Jun. 2013. http://dx.doi.org/10.5624/isd.2013.43.2.85 
ASANZA, S.; CISNEROS, G. J.; NIEBERG, L. G. Comparison of Hyrax and bonded expansion appliances. Angle Orthod., v. 67, n. 1, p. 15-22, Feb. 1997.

BAYSAL, A.; UYSAL, T.; VELI, I.; OZER, T.; KARADEDE, I.; HEKIMOGLU, S. Evaluation of alveolar bone loss following rapid maxillary expansion using cone-beam computed tomography. Korean J Orthod., v. 43, n. 2, p. 83-95, Apr. 2013. http://dx.doi.org/10.4041/kjod.2013.43.2.83

BIEDERMAN, W. A hygienic appliance for rapid expansion. J Pract Orthod., v. 2, n. 2, p. 67-70, Feb. 1968.

BISHARA, S. E.; STALEY, R. N. Maxillary expansion: clinical implications. Am J Orthod Dentofacial Orthop., v. 91, n. 1, p. 3-14, Jan. 1987. http://dx.doi.org/10.1016/0889-5406(87)90202-2

COHEN, M.; SILVERMAN, E. A new and simple palate splitting device. J Clin Orthod., v. 7, n. 6, p. 368-9, Jun. 1973.

FARRONATO, G.; MASPERO, C.; RUSSO, E.; PERITI, G.; FARRONATO, D. Headache and transverse maxillary discrepancy. J Clin Pediatr Dent., v. 33, n. 1, p. 67-74, Fall 2008.

http://dx.doi.org/10.17796/jcpd.33.1.j82n127877250863

GARIB, D. G.; HENRIQUES, J. F.; JANSON, G.; FREITAS, M. R.; COELHO, R. A. Rapid maxillary expansion--tooth tissue-borne versus tooth-borne expanders: a computed tomography evaluation of dentoskeletal effects. Angle Orthod., v. 75, n. 4, p. 548-57, Jul. 2005.

GARRETT, B. J.; CARUSO, J. M.; RUNGCHARASSAENG, K.; FARRAGE, J. R.; KIM, J. S.; TAYLOR, G. D. Skeletal effects to the maxilla after rapid maxillary expansion assessed with cone-beam computed tomography. Am J Orthod Dentofacial Orthop., v. 134, n. 1, p. 8-9, Jul. 2008.

http://dx.doi.org/10.1016/j.ajodo.2008.06.004- http://dx.doi.org/10.1016/j.ajodo.2007.11.024

HAAS, A. J. Palatal expansion: just the beginning of dentofacial orthopedics. Am J Orthod., v. 57, n. 3, p. 219-55, Mar. 1970. http://dx.doi.org/10.1016/0002-9416(70)90241-1

IWASAKI, T.; TAKEMOTO, Y.; INADA, E.; SATO, H.; SUGA, H.; SAITOH, I.; KAKUNO, E.; KANOMI, R.; YAMASAKI, Y. The effect of rapid maxillary expansion on pharyngeal airway pressure during inspiration evaluated using computational fluid dynamics. Int J Pediatr Otorhinolaryngol., v. 78, n. 8, p. 1258-64, Aug. 2014. http://dx.doi.org/10.1016/j.ijporl.2014.05.004

LAGRAVÈRE, M. O.; CAREY, J.; HEO, G.; TOOGOOD, R. W.; MAJOR, P. W. Transverse, vertical, and anteroposterior changes from bone-anchored maxillary expansion vs traditional rapid maxillary expansion: a randomized clinical trial. Am J Orthod Dentofacial Orthop., v. 137, n. 3, p. 304.e1-12, Mar. 2010.

http://dx.doi.org/10.1016/j.ajodo.2009.09.016

http://dx.doi.org/10.1016/j.ajodo.2009.10.004

REED, N.; GHOSH, J.; NANDA, R. S. Comparison of treatment outcomes with banded and bonded RPE appliances. Am J Orthod Dentofacial Orthop., v. 116, n. 1, p. 31-40, Jul. 1999.

http://dx.doi.org/10.1016/S0889-5406(99)70300-8

RIEDEL, R. A. The relation of maxillary structures to cranium in malocclusion and in normal occlusion. Angle Orthod., v. 22, n. 3, p. 142-5, Jul. 1952.

RODRIGUES, A. D. O. P.; MONINI, A. D. A. C.; GANDINI, L. G. JR.; SANTOS-PINTO, A. D. Rapid palatal expansion: a comparison of two appliances. Braz. Oral Res., v. 26, n. 3, p. 242-8, May-Jun, 2012. http://dx.doi.org/10.1590/S1806-83242012000300010

SARVER, D. M.; JOHNSTON, M. W. Skeletal changes in vertical and anterior displacement of the maxilla with bonded rapid palatal expansion appliances. Am J Orthod Dentofacial Orthop., v. 95, n. 6, p. 462-66, Jun. 1989. http://dx.doi.org/10.1016/0889-5406(89)90409-5 